Reprod. Nutr. Dévelop., 1988, 28 (4 B), 1105-1112

\title{
Anti-Müllerian hormone in sheep follicles (1)
}

\author{
Jacqueline BÉZARD, B. VIGIER (*), Dien TRAN (*), P. MAULÉON, Nathalie \\ JOSSO $\left({ }^{*}\right)$
}

Station de Physiologie de la Reproduction, I.N.R.A. Nouzilly 37380 Monnaie.

(*) Unité de Recherches sur /'Endocrinologie du Développement INSERM. Hôpital des Enfants-Malades, 75743 Paris Cedex.

Summary. The purpose of this work was to study anti-Müllerian hormone (AMH) secretion during ovarian development in sheep before and after birth. We used avidinbiotin immunocytochemistry and a monoclonal antibody specific for ruminant $\mathrm{AMH}$. Only granulosa cells have an immunoreactivity; this immunoreactivity was influenced by animal age and by the degree of follicular development. In the fetus, no immunoreactivity was detected in somatic cells of ovigerous cords at 70 days post-coitum (p.c.) or in primordial and growing follicles at 100 and 120 days p.c. A faint reaction was only seen occasionally in a few cells belonging to preantral follicles at 120 days p.c. AMH was never detected in primordial follicles in ovaries of 144 days p.c., at birth, at $8,97,145$ days post-natal or in adult ovaries. A faint reaction, elicited in small growing follicles, increased with follicle size to become more intense in antral follicles. Immunoreactivity was strongly positive in granulosa cells, especially in those lining the antral cavity and close to the oocyte, whereas there was little or no reactivity in peripheral cells near the basal membrane. Follicles without $\mathrm{AMH}$ reactivity were found at all times and their number decreased with age.

\section{Introduction.}

Anti-Müllerian hormone (AMH), responsible for Müllerian duct regression in male fetuses (Jost, 1953), is mainly produced by immature Sertoli cells (Blanchard and Josso, 1974 ; Tran and Josso, 1982; Hayashi et al., 1984). Anti-Müllerian activity has also been demonstrated in embryonic and adult chick ovary (Hutson, Ikawa and Donahoe, 1981). Bioactive AMH released by the granulosa cells has been purified from follicular fluid of mature bovine ovaries (Vigier et al., 1984); the synthesis of this ovarian AMH was located by radioimmunoassay and cytochemistry in granulosa cells by Vigier et al. (1984) and Takahasi et al. (1986). Using a sensitive immunocytochemical method based on a monoclonal antibody specific for ruminant $A M H$, in the present work we examined the ontogeny of ovarian $\mathrm{AMH}$ in granulosa cells during fetal and post-natal gonadal development in the ewe.

(1) This work has been published in part (Bézard et al., 1987). 


\section{Material and methods.}

Ovaries were obtained immediately after slaughter in fetuses aged 70,100 , 120,144 days post coitum, in lambs at birth, at 8,97 and 145 days post-natal and in adults. Four to six gonads were observed in different animals at each age. Fetal testes at 60,100 and 120 days p.c. were used as positive controls. Whole fetal gonads and $5 \mathrm{~mm}^{3}$ blocks of post-natal ovaries were fixed in sodium phosphate buffer $0.1 \mathrm{M}, \mathrm{pH} 7.4$, containing $2 \%$ paraformaldehyde, $1.5 \%(\mathrm{~L}(+)$-lysine monochlorhydrate, $0.2 \%$ sodium metaperiodate and saponin (Sigma Chemicals, St Louis, MO, USA), $0.02 \%$ for fetal and $0.04 \%$ for post-natal tissue, for $2 \mathrm{~h}$ at room temperature as described by McLean and Nakane (1974). Fixation was followed by 3 washes of sodium phosphate buffer, $0.1 \mathrm{M}, \mathrm{pH} 7.4$, at $4{ }^{\circ} \mathrm{C}$ over a 2 -h period. The specimens, placed for $1 \mathrm{~h}$ at room temperature in the same buffer containing $10 \%$ dimethylsulphoxide, were then frozen and stored in liquid nitrogen until processed.

Cryostat sections of $10 \mu \mathrm{m}$ were recovered on gelatin-coated slides. The sections were washed for $1 \mathrm{~h}$ at room temperature in Dulbecco phosphatebufferedsaline (PBS) (Dulbecco A, Biolyon, Dardilly, France), immersed for $5 \mathrm{~min}$ in $3 \%$ hydrogen peroxide to neutralize endogenous peroxidases, and washed again in PBS, 3 times $5 \mathrm{~min}$ each. They were then incubated in $10 \%$ ovalbumin solution to minimize non-specific reactions, drained and exposed overnight at $4{ }^{\circ} \mathrm{C}$ to monoclonal antibody 61 , diluted $4 \mu \mathrm{g} / \mathrm{ml}$ in PBS containing $0.1 \%$ ovalbumin and $0.05 \%$ saponin. Monoclonal antibody 61 is a mouse IgGI with an affinity constant of $5.8 \times 10^{-9} \mathrm{M}$ towards bovine $\mathrm{AMH}$ and it is zoospecific for ruminant AMH (Legeai et al., 1986). After washing in PBS, the sections were incubated for $2 \mathrm{~h}$ at room temperature in biotinylated sheep immunoglobulin directed against mouse IgG (Amersham-France, Les Ulis) at the $1 / 300$ dilution recommended by the manufacturer, rinsed again in PBS, and incubated for $1 \mathrm{~h}$ in streptavidin-biotinylated peroxidase complex (Amersham). The sections were rinsed in PBS and peroxidase was revealed in $0.05 \%$ diaminobenzidine in PBS containing $0.035 \%$ hydrogen peroxide. Finally, the sections were washed in distilled water, dehydrated, mounted and examined under the light microscope. Sections of fetal ovine testicular tissue were included in each series to serve as positive controls of the reaction. Negative controls, also performed for each batch, were obtained by substituting non-immune mouse immunoglobulin, or monoclonal antibody exhausted by an excess of bovine $\mathrm{AMH}$, for the first antibody.

\section{Results.}

Results concerning the location of $\mathrm{AMH}$ immunoreactivity in sheep ovarian follicles have been summarized according to age in table 1 .

No immunoreactivity was detected in fetal ovaries of 70 days p.c. showing numerous ovigerous cords containing oogonia and oocytes in meiotic prophase and a few primordial follicles in the deepest part of the gonad. 
TABLE 1

Immunocytochemical reaction for AMH in sheep ovarian follicles at various ages.

\begin{tabular}{lccccc}
\hline \multirow{2}{*}{ Age (days) } & $\begin{array}{c}\text { No. of } \\
\text { gonads } \\
\text { studied }\end{array}$ & \multicolumn{4}{c}{$\begin{array}{c}\text { Immuno-reactivity of granulosa } \\
\text { celis in follicles : }\end{array}$} \\
\cline { 3 - 6 } 70 post coitum & 4 & Primordial & Growing & Preantral & Antral \\
\cline { 2 - 6 } 100 post coitum & 4 & - & None & None & None \\
120 post coitum & 4 & - & - & - & None \\
144 post coitum & 4 & - & - & $+/-$ & None \\
Birth* & 6 & - & + & + & + \\
8 post partum & 4 & - & + & + & + \\
97 post partum & 4 & - & + & + & + \\
145 post partum & 4 & - & + & + & + \\
Adult & 6 & - & + & + & + \\
\hline
\end{tabular}

* Birth $=145$ days post coitum.

\# Positive in only 2 gonads out of 6.

At 100 days p.c., all the germ cells were enclosed in primordial follicles, and at 120 days p.c. growing follicles with 2-6 granulosa cell layers were found in the innermost regions; in some dispersions of granulosa cells, an antral cavity was visible. In these last, a faint immunoreactivity was occasionally detected in a few cells belonging to preantral follicles, but it was always absent in the somatic cells of ovigerous cords, primordial and small growing follicles.

Fetal ovaries just before birth, 144 days p.c. and post-natal ovaries from term to adulthood contained follicles in all stages of development: primordial, growing, preantral and antral.

The degree of $\mathrm{AMH}$ immunoreactivity was influenced by the stage of follicular maturation. No immunoreactivity was observed in primordial follicles, except in one experimental series in which a few cuboidal granulosa cells seemed to show a faint reaction. The proportion of growing follicles with detectable AMH increased with the degree of follicular development. Some small growing follicles showed reactivity and in this case all the granulosa cell layers (2-6) were faintly stained. As growth continued, more 6 -layer follicles and preantral follicles had an $\mathrm{AMH}$ immunoreactivity which became stronger in the innermost layers close to the oocyte and decreased in those adjoining the basal membrane (fig. 1). Before birth at 144 p.c., a few of the small antral follicles showed faint $A M H$ immunoreactivity (fig. 3). After birth most, but not all (fig. 7), antral folticles, whatever their size, were stained by the reaction for AMH (figs. 4-5, 6). Stain was deposited in the cytoplasm of granulosa cells, particularly along their plasma membrane. The intensity of the immunocytochemical reaction varied with the location of the granulosa cells: peripheral cells lining the antral cavity and the oocyte were strongly positive (figs. 5,6 ). Reactive cytoplasmic protrusions of the cumulus cells could be followed across the zona pellucida and perivitelline space (fig. 5). 
1

सथ।

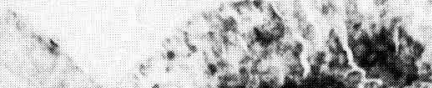

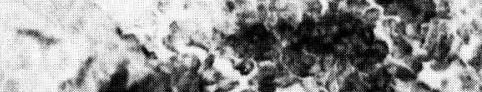

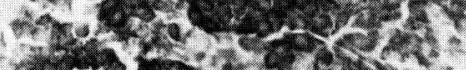

s. $545 \times$
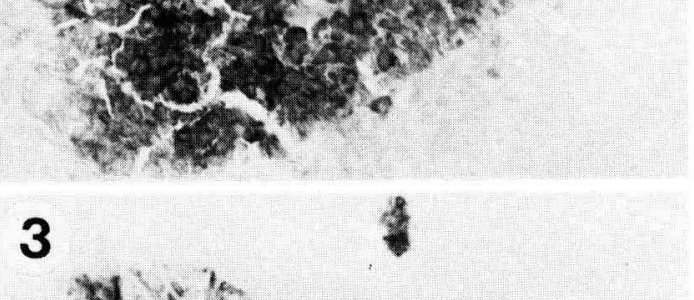

$\therefore$ 6rints

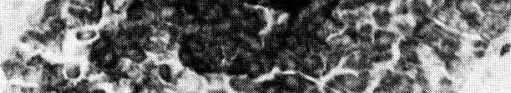

2

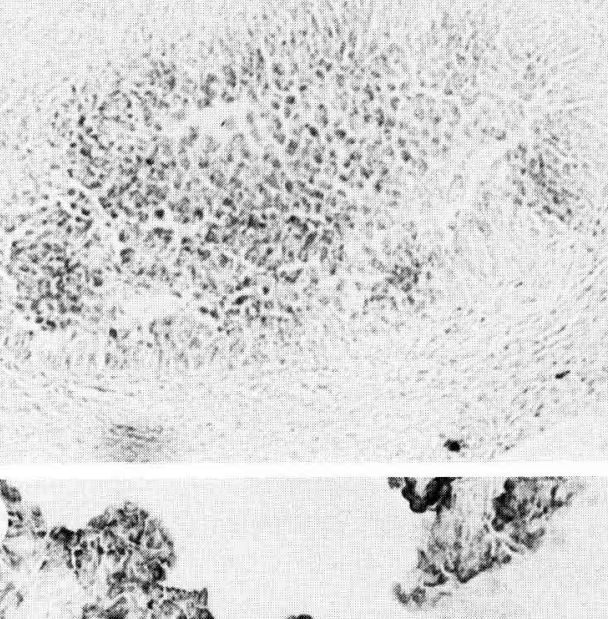

$+x^{2}, 3,2$

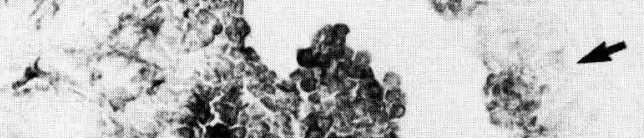

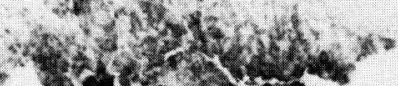
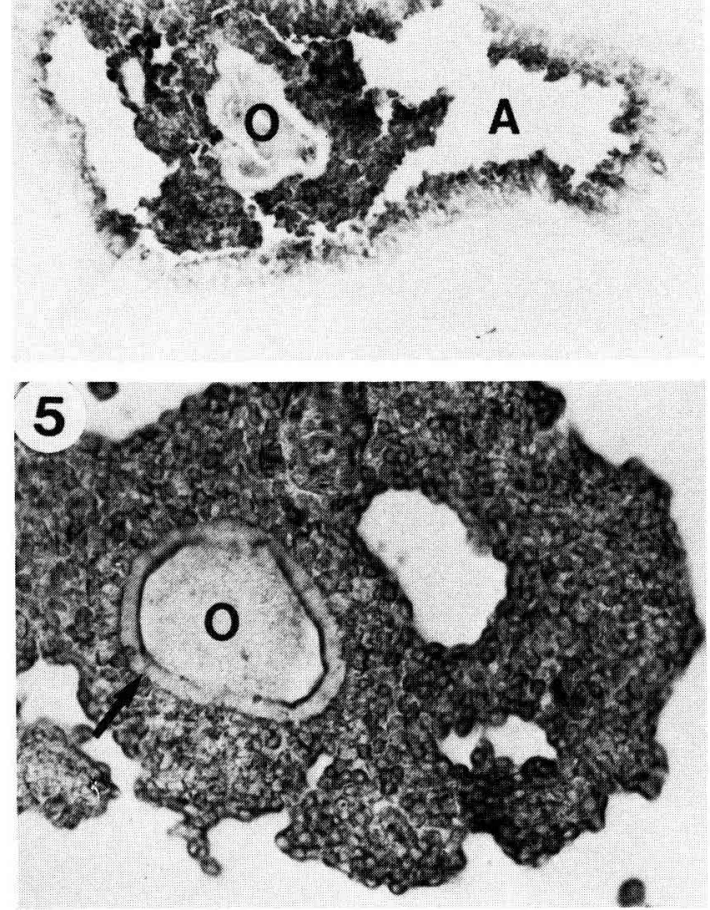

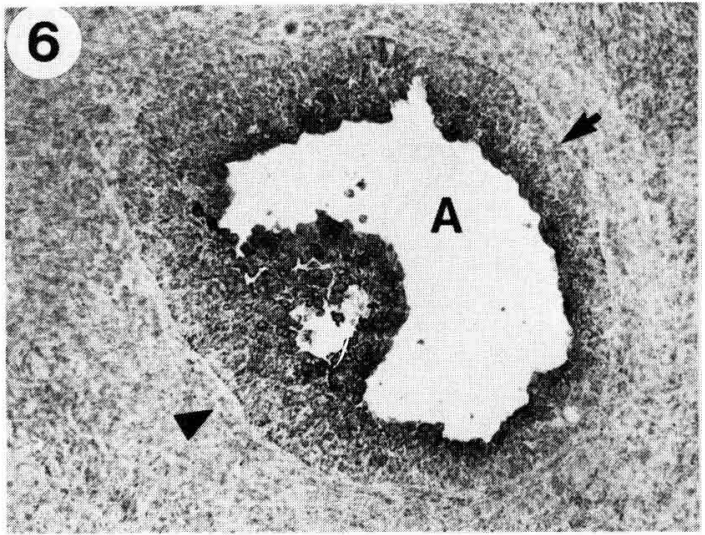

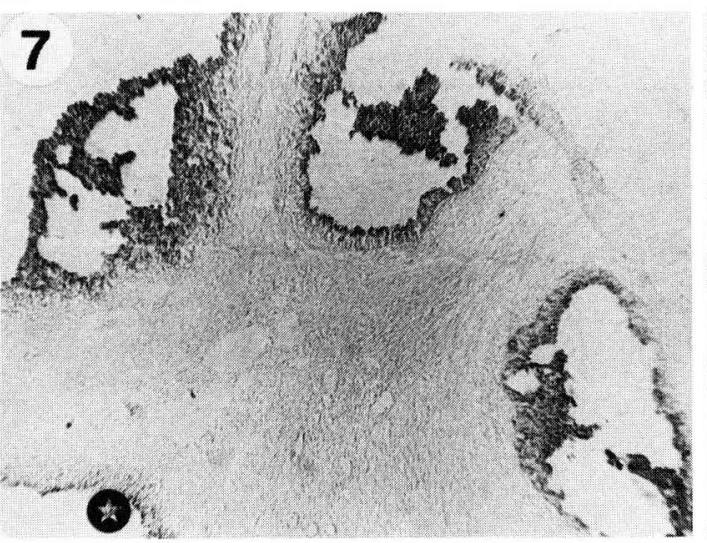

8

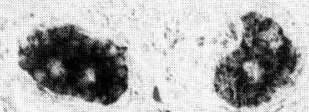

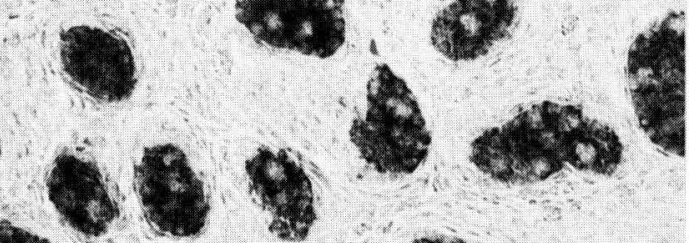
$x^{3}, x^{2}=$

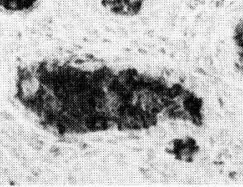


Groups of immunoreactive granulosa cells were occasionally seen in the cavity of large follicles. Thecal cells never showed a positive reaction (figs. 6, 7).

The granulosa cells were always unstained in controls of specificity of the $\mathrm{AMH}$ reaction using a non-specific first antibody (fig. 2) or anti-AMH monoclonal antibody exhausted by an excess of bovine AMH (results not shown).

In fetal testicular tissue (used as a positive control at 60-100 and 120 days p.c.) intense $\mathrm{AMH}$ immunoreactivity, much higher than that observed in granulosa cells, whatever the ovarian age, was always present in the cytoplasm of the Sertoli cells (fig. 8).

\section{Discussion.}

Using a monoclonal antibody specific for ruminant AMH (Legeai et al., 1986) and a sensitive streptavidin-biotin technique (Tran et al., 1987), we have shown that ovine granulosa cells can produce AMH shortly before birth and until adulthood, as found in vitro for adult bovine granulosa cells by radioimmunoassay (Vigier et al., 1984) and more recently by cytochemistry in 1 -day to 5-year old bovine ovaries (Takahashi, Koide and Donahoe, 1986). The specificity of AMH immunocytochemical detection was proved by the capacity of purified bovine $\mathrm{AMH}$ to abolish the reaction when used to exhaust the first antibody.

The amount of AMH production detected in ovine ovaries was always relatively low compared to the high level of $A M H$ production detected in fetal ovine Sertoli cells (fig. 8). This fact is in agreement with the small amount of $A M H$ produced in vitro by adult granulosa cells (Vigier et al., 1984). In contrast, chicken embryonic and post-natal ovarian tissues exhibited relatively high anti-Müllerian bioactivity as demonstrated by their ability to trigger fetal rat Müllerian duct regression in vitro (Hutson et al., 1981).

In ovine ovaries, $\mathrm{AMH}$ production varied with the age of the gonad and the developmental stage of the follicles. A faint positive AMH reaction was first observed at 120 days p.c. in only a few preantral follicles. The AMH reactivity increased slowly with age and progressively concerned all types of follicles.

FIG. 1-8. - Cryostat sections $(10 \mu \mathrm{m})$ after immunohistochemical reaction for $A M H$.

FIG. 1. - Large growing follicle in 97 day-o/d p.p. ovary: stronger reactivity is observed in the innermost layers of granulosa cells. $(\times 200)$.

FIG. 2. - Some follicle as in fig. 1: no reaction is observed using a non-specific first antibody. $(\times 200)$.

FIG. 3. - Small antral follicle in perinatal ovary, 144 days p.c. Reaction is localized to granulosa cells lining the oocyte $(O)$ and the antrum $(A) .(\times 125)$.

FIG. 4. - Antral follicle in 97 day-old p.p. ovary. The granulosa cells near the oocyte, present on the next section, are more positive than ones near the basal membrane $(\leftarrow) .(\times 200)$.

FIG. 5. - Antral follicle in adult ovary : strong $A M H$ reactivity in cumulus cells and in their protrusions across the zona pellucida $(\leftarrow)$ and the oocyte $(\bigcirc),(\times 200)$.

FIG. 6. - Antral follicle in a 97 day-old p.p. ovary. Note the immunoreactivity gradient: stronger in granulosa cells lining the antral cavity $(A)$ and weaker in those close to the basal membrane $(\leftarrow)$. No immunoreactivity is observed in the thecal cells $(4) .(\times 125)$.

FIG. 7. - Adult ovary with four antral follicles: three are positive and one is unreacted $(\star) .(\times 50)$.

FIG. 8. - Fetal testis (100 days p.c.). Seminiferous cords show a strongly positive reaction. $(\times 200)$. 
After puberty, $\mathrm{AMH}$ reactivity was essentially influenced by the location of the granulosa cells within the follicle. In antral follicles, the progression of maturation was accompanied by the establishment of an immunoreactivity gradient between mural granulosa cells on one hand, which showed no or low $\mathrm{AMH}$ content, and granulosa cells lining the antrum and in the cumulus oophorus, on the other, which had a consistently high AMH content.

The heterogeneity of the granulosa cell population is well known. Studies carried out in rats show that during Graafian follicle growth, only granulosa cells in the cumulus proliferate (Hirshfield and Midgley, 1984) and can be considered as stem cells. When challenged by FSH, peripheral granulosa cells located near the basal lamina undergo terminal cytodifferentiation, characterized by the acquisition of $\mathrm{LH} / \mathrm{hCG}$ receptor, steroidogenic enzymes and lipid droplets (reviewed by O'Shea, 1981 ; Erickson et al., 1985) whereas prolactin receptor development and reactivity to a monoclonal antibody raised to a mammary cell line (Erickson et al., 1985) is restricted primarily to the cumulus and the innermost granulosa cells.

There is evidence (reviewed by Erickson, 1983) to support the hypothesis that the position of the granulosa cell in the follicle determines how it will differentiate in response to FSH stimulation. Our results show that $\mathrm{AMH}$ immunoreactivity is confined to the stem cell population of granulosa cells incapable of undergoing terminal differentiation under FSH stimulation.

In ewes at all stages studied after birth, some follicles showed no AMH reactivity and their number varied with ovary age ; they were few in the adult stage and more numerous in the youngest ones. At present it is not possible to know if this observation is related to the process of follicular atresia, undetectable here in the frozen tissue.

Does AMH play a physiological role in the ovary? Bovine $\mathrm{AMH}$, which is probably the testicular factor responsible for the sterilization and masculinization of the freemartin ovary (Jost, Vigier and Prépin, 1972), has been shown to inhibit the proliferation of rat oogonia in vitro but has no deleterious effect on oocytes enclosed in primordial follicles (Vigier et al., 1987).

Two remaining possibilities must be considered. AMH could be the factor responsible for the arrest of meiotic prophase at the dictyate phase in fetal oocytes enclosed in primordial follicles, but the absence of $\mathrm{AMH}$ immunoreactivity in granulosa cells of primordial follicles does not favour this hypothesis. AMH could also be related in some way to the oocyte maturation inhibitor which holds meiosis in abeyance until ovulation (Vigier et al., 1984). The localization of AMH immunoreactivity in granulosa cells lining the antrum and the oocyte, and the immunoreactivity of the cumulus cell protrusions which extend across the zona pellucida into the germ cell cytoplasm (Gondos, 1970; Szöllösi, 1975) support this possibility. However, up to now, meiosis-inhibiting action has been reported for the partially purified fraction of bovine $\mathrm{AMH}$, using the rat oocyte as a target organ (Takahashi, Koide and Donahoe, 1986), but not for completely purified bovine AMH using the same experimental model (Tsafriri et al., 1988). 
Acknowledgements. - We wish to thank Jacqueline Campargue for technical assistance and Colette Masset for manuscript preparation. The work was supported by a grant from I.N.R.A. : ATP « Hormones hypophysaires et fonction de reproduction chez les Vertébrés » (1985).

\section{Résumé. Hormone anti-Müllerienne dans les follicules ovariens chez la brebis.}

Ce travail a eu pour objectif l'étude de la sécrétion de l'hormone anti-Müllerienne (AMH) au cours du développement ovarien chez la brebis avant et après la naissance. La détection histoimmunochimique de cette hormone a été réalisée à l'aide du système avidin-biotin et d'un anticorps monoclonal spécifique de l'AMH des ruminants. Seules les cellules de la granulosa présentent une immunoréactivité influencée par l'âge de l'animal et par le degré de développement des follicules. Chez le fœtus, aucune réactivité n'est observée dans les cellules somatiques des cordons ovigères dans les ovaires de 70 jours p.c. ainsi que dans les follicules primordiaux et en croissance dans ceux de 100 et 120 jours p.c. Une faible réactivité a été vue occasionnellement dans quelques cellules de follicules préantraux à 120 jours p.c. Dans les ovaires prélevés à 144 jours p.c., à la naissance, à 8-97-145 jours p.p. et à l'âge adulte, l'AMH n'est jamais détectée dans les follicules primordiaux. Une faible réactivité est trouvée dans les follicules débutant leur croissance. Elle augmente avec la taille du follicule pour devenir plus intense dans les follicules à antrum. L'immunoréactivité est plus marquée dans les cellules de la granulosa bordant la cavité antrale et dans celles proche de l'ovocyte alors qu'elle est faible ou absente dans les cellules périphériques situées le long de la membrane basale.

A chaque stade étudié, certains follicules ne présentent pas d'immunoréactivité leur nombre décroît avec l'âge.

\section{References}

BÉZARD J., VIGIER B., TRAN D., MAULÉON P., JOSSO N., 1987. Immunocytochemical study of anti-Müllerian hormone in sheep ovarian follicles during fetal and post-natal development. J. Reprod. Fert., 80, 509-516.

BLANCHARD M. G., JOSSO N., 1974. Source of the anti-Müllerian hormone synthesized by the fetal testis : Müllerian-inhibiting activity of fetal bovine Sertoli cells in tissue culture. Pediatr. Res., 8, 968-971.

ERICKSON G. F., 1983. Primary cultures of ovarian cells in serum-free medium as models of hormone-dependent differentiation. Mol. cell. Endocrinol., 29, 21-29.

ERICKSON G. F., HOFEDITZ C., UNGER M., ALLEN W. R., DULBECCO R., 1985. A monoclonal antibody to a mammary cell line recognizes two distinct subtypes of ovarian granulosa cells. Endocrinology, 117, 1490-1499.

GONDOS B., 1970. Granulosa cell-germ cell relationship in the developing rabbit ovary. J. Embryol. exp. Morphol., 23, 419-426.

HAYASHI H., SHIMA H., YAHASHI K., TRELSTAD R. L., DONAHOE P. K., 1984 . Immunocytochemical localization of Müllerian inhibiting substance in the rough endoplasmic reticulum and Golgi apparatus in Sertoli cells of the neonatal calf testis using a monoclonal antibody. J. Histochem. Cytochem., 32, 649-654.

HIRSCHFIELD A. N., MIDGLEY A. R., 1984. Morphometric analysis of follicular development in the rat. Biol. Reprod., 19, 597-605.

HUTSON J. M., IKAWA H., DONAHOE P. K., 1981. The ontogeny of Müllerian inhibiting substance in the gonads of the chicken. J. Pediatr. Surg., 16, 822-827.

JOST A., 1953. Problems of fetal endocrinology : the gonadal and hypophyseal hormones. Rec. Prog. Horm. Res., 8, 379-418.

JOST A., VIGIER B., PRÉPIN J., 1972. Freemartins in cattle : the first steps of sexual organogenesis. $J$. Reprod. Fertil., 29, 349-379. 
LEGEAI L., VIGIER B., TRAN D., PICARD J. Y., JOSSO N., 1986. Monoclonal antibodies raised against bovine anti-Müllerian hormone : bovine, ovine and caprine hormones share a set of identical epitopes. Biol. Reprod., 35, 1217-1225.

MCLEAN I. W., NAKANE P. K., 1974. Periodate-lysine-paraformaldehyde fixative : a new fixative for immunoelectron microscopy. J. Histochem. Cytochem., 22, 1077-1083.

O'SHEA J. D., 1981. Structure-function relationships in the wall of ovarian follicle. Aust J. biol. Sci. 34, 379-394.

SZÖlıÖSI D., 1975. Ultrastructural aspects of oocyte maturation and fertilization in mammals. In THIBAULT C. La fécondation. Masson, Paris, 13-35.

TAKAHASHI M., KOIDE S. S., DONAHOE P. K., 1986. Müllerian inhibiting substance as oocyte meiosis inhibitor. Mol. cell. Endocr., 47, 225-234.

TAKAHASHI M., HAYASHI M., MANGANARO T. F., DONAHOE P. K., 1986. The ontogeny of Müllerian Inhibiting Substance in granulosa celis of the bovine ovarian follicle. Biol. Reorod., 35, 447-453.

TRAN D., JOSSO N., 1982. Localization of anti-Müllerian hormone in the rough endoplasmic reticulum of the developing bovine Sertoli cell using immunocytochemistry with a monoclonal antibody. Endocrinology, 111, 1562-1567.

TRAN D., PICARD J. Y., CAMPARGUE J., JOSSO N., 1987. Immunocytochemical detection of anti-Müllerian hormone in Sertoli cells of various mammalian species, including man. $J$. Histochem. Cytochem., 33, 733-743.

TSAFRIRI A., PICARD J. Y., JOSSO N., 1988. Immunopurified anti-Müllerian hormone does not inhibit spontaneous resumption of meiosis in vitro of rat oocytes. Biol. Reprod., 38, 481-485.

VIGIER B., PICARD J. Y., TRAN D., LEGEAI L., JOSSO N., 1984. Reproduction of anti-Müllerian hormone: another homology between Sertoli and granulosa cells. Endocrinology, 114, $1315-1320$.

VIGIER B., PICARD J. L., CAMPARGUE J., FOREST M. G., HEYMAN Y., JOSSO N., 1985. Mol. cell. Endocrinol., 43, 141-150.

VIGIER B., WATRIN F., MAGRE S., TRAN D., JOSSO N., 1987. Purified bovine AMH induces a characteristic freemartin effect in fetal rat prospective ovaries exposed to it in vitro. Development, 100, 43-55. 